\title{
SENGIR-TAM 2: NEW RESEARCH ON THE SITE IN EASTERN ARAL SEA REGION
}

(C) 2019

Kurmankulov Zholdasbek, candidate of historical sciences, chief researcher of Prehistoric Department Utubayev Zhanbolat Raimkulovich, candidate of historical sciences, senior researcher of Prehistoric Department A.Kh. Margulan Institute of Archaeology (Almaty, Republic of Kazakhstan)

Abstract. The paper presents the excavations results from the new site of the early Iron Age Sengir-tam 2, located in the lower stream of the Syr Darya River in Kyzylorda Region. The site is a grave consisting of 23 ground mounds. There are west and east groups located in chain order and oriented along the west-east line. To date, six mounds have been explored on the site. It has been revealed that the grave was robbed in ancient times. Archaeological works on the high ground of Sengir-tam 2 showed that burials were carried out here for a long time. The excavations revealed pieces of horse tack, iron knives, beads and helmet plaque, ceramics. The burial rite and equipment recorded on the site have direct similarities with other burial complexes of Eastern Aral Sea, particularly among the materials of the graves of South Tagisken and Uigarak dated by VII-V centuries BC. It should be noted that Sengir-tam 2 is still the third site discovered in the interfluve of Incardarya and Zhanadarya. According to the materials received, the population of Eastern Aral Sea region had links with the other cultures of the Saka time from Altay in the east to the Black Sea in the west.

Keywords: Eastern Aral Sea region; Syr Darya; Sengir-tam; Early Iron Age; Saka; burial ground; highland; complex; barrow; burial rite; burial; stratigraphy; dating; postholes; stock; finds; material; bronze; iron; ceramics; horse tack; beads; knife; sharpening stone.

\section{ПАЛЕОПАТОЛОГИЧЕСКИЕ ОСОБЕННОСТИ НАСЕЛЕНИЯ ЭПОХИ ПОЗДНЕЙ БРОНЗЫ ПО АНТРОПОЛОГИЧЕСКИМ МАТЕРИАЛАМ ИЗ МОГИЛЬНИКОВ В ОКРЕСТНОСТЯХ СЕЛА КРАСНОСАМАРСКОЕ САМАРСКОЙ ОБЛАСТИ}

(C) 2019

\section{Перерва Евгений Владимирович, кандидат исторических наук,} начальник научно-организационного отдела

Волгоградский институт управления - филиал Российской академии народного хозяйства и государственной службы при Президенте Российской Федерации (2. Волгоград, Российская Федерация)

Капинус Юлия Олеговна, научный сотрудник

Волго-Уральского центра палеоантропологических исследований

Самарский государственный соџиально-педагогический университет (2. Самара, Российская Федераџия)

Аннотация. Работа посвящена анализу антропологических материалов, относящихся к срубной культуре, полученных при раскопках в 2010 и 2018 гг. курганов возле села Красносамарское Кинельского района Самарской области. Были изучены костные останки 103 индивидов. В процессе исследования применялась стандартная программа фиксации патологических состояний на костях человека. В результате проведенной работы удалось установить, что для населения эпохи поздней бронзы, погребенного в курганах близ села Красносамарское, была характерна высокая детская смертность и сравнительно небольшая продолжительность жизни мужчин. У исследуемой серии индивидов выделяется специфический патологический комплекс на зубной системе, указывающий на мясо-молочную специализацию в диете. Широкое распространение на костных останках детей маркеров нехватки микроэлементов в организме свидетельствует о воздействии негативных факторов окружающей и социальной среды, например, голодоморов или паразитарных инвазий. Высокая частота встречаемости дискретно-варьирующих признаков на костях посткраниального скелета указывает на то, что в курганах могильника Красносамарский IV, возможно, захоронено близкородственное население. Распространение специфических травматических повреждений, а также положительная корреляция их с заболеваниями суставов и позвоночника дают возможность сделать предположение о том, что их появление связано с бытовой или профессионально-хозяйственной деятельностью.

Ключевые слова: палеоантропология; палеопатология; болезни древних людей; срубная культура; эпоха средней бронзы; могильники; Среднее Поволжье; палеодемография; кариес; зубной камень; внутренний лобный гиперостоз; травмы; дегенеративные изменения суставов и позвоночника.

Изучение палеопатологических особенностей древнего населения сегодня становится все более популярным направлением в биологической и исторической науке. Исследование ископаемых костных останков человека и анализ характера распространения различного рода заболеваний, фиксация различного рода травм и искусственных модификаций поз- воляют исследователям по-новому взглянуть на специфику хозяйственно-культурной жизни и особенностей социальной адаптации человеческих популяций к окружающей среде.

Вообще изучение антропологических материалов эпохи бронзы Восточной Европы было положено Г.Ф. Дебецом [1]. Большое значение для понимания 
процессов культурогенеза эпохи бронзы имеют работы В.В. Гинзбурга [2], Б.В. Фирштейн [3], А.В. Шевченко [4], Е.Ф. Батиевой [5], М.А. Балабановой [6], А.А. Казарницкого [7], А.А. Хохлова [8; 9] и др.

Что же касается анализа антропологических материалов бронзового века с помощью палеопатологического подхода обследования, то впервые он был реализован в монументальном труде Д.Г. Рохлина [10]. Здесь ученый впервые проводит патологический анализ нескольких костяков афанасьевской культуры и андроновской эпохи, найденных на территории Алтайского края [10, с. 191].

Большое значение для развития палеопатологии имеет книга В.Я. Дэрумса «Болезни и врачевание в древней Прибалтике», в которой целая глава посвящена изучению антропологических материалов бронзового века [11].

Собственно, патологическое описание материалов эпохи поздней бронзы впервые находятся в работе С.И. Круц. Ученой описаны палеопатологические отклонения на черепах срубной культуры степного Поднепровья [12].

Большое значение для развития представлений о характере распространения заболеваний и особенностей образа жизни населения эпохи поздней бронзы имеют работы А.П. Бужиловой. Исследователем были изучены материалы таких могильников, как Каргалы (Оренбургская область) и Экажево I и II (республика Ингушетия), датирующиеся срубным временем [13; 14].

В фундаментальном труде «Ноomo sapiens: история болезни» А.П. Бужилова обобщила полученные результаты исследования по степным и лесостепным культурам бронзы Восточной Европы. Ученым сделаны важные заключения по демографическим показателям эпохи поздней бронзы, характеру распространения зубных патологий, заболеваний обмена веществ, а также по особенностям травматизма $[15$, c. $125-126]$.

Е.Ф. Батиевой были изучены материалы Подонья и Приазовья эпохи бронзы, что позволило исследователю оценить особенности палеодемографической ситуации в это время [5]. Ученым также были проанализированы антропологические материалы из срубных погребений междуречья Дона и Чира, в результате чего Е.Ф. Батиева указала на краниологические особенности, характерные для групп поздней бронзы, а также на палеодемографические и палеопатологические характеристики [16, с. 162-167].

Е.С. Аристова и др. установили особенности пищевой специализации населения барабинских степей эпохи неолита-бронзы. Изучение материалов срубного времени позволило авторам указать, что население этого времени в диете специализировалось на мясном комплексе, а злаки практически не употреблялись [17, с. 19].

С.В. Шараповой с соавторами были исследованы антропологические материалы могильника Неплюевский, датирующегося эпохой поздней бронзы и происходящего с территории Южного Зауралья. Ученые изучили костные останки ребенка 2-4 лет, у которого был зафиксирован поротический гиперостоз, формирование которого авторы связали с развитием инфекционного заболевания [18, с. 202].

В.В. Куфтериным и А.И. Нечволодой исследован антропологический материал из кургана срубно-ала- кульской культуры, могильника Селивановский II Южного Зауралья. Изучив костные останки 23 индивидов, авторы указали, что для рассматриваемой выборки были характерны невысокие частоты встречаемости с небольшим разнообразием остеологически фиксируемых патологических индикаторов [19, с. 86].

С.С. Тур и М.П. Рыкун изучили обширные материалы населения андроновской культуры Алтая. Их исследование показало, что для группы эпохи поздней бронзы были характерны такие критерии патологического профиля, как отсутствие кариеса, распространение зубного камня, пародонтоза, остеоартроза височно-нижнечелюстных суставов, а также травм зубов. У андроновцев Алтая наблюдается малая частота одонтогенного остеомиелита и прижизненной утраты зубов, а также повышение показателей встречаемости поротического гиперостоза у детей. Выявленные особенности С.С. Тур и М.П. Рыкун считают результатом воздействия местных природно-климатических условий, а также специфики социальноэкономического развития палеогруппы [20, с. 197].

Материалы срубного времени из могильника Михайловский II, расположенного в Кинельском районе Самарской области, были обследованы Ю.О. Капинус. В результате изучения выборки, состоящей из 18 скелетов, ученой удалось установить, что для населения эпохи бронзы Среднего Поволжья были характеры высокие частоты встречаемости деформирующих артрозов, травм. Также анализ костных образцов позволил выявить патогены бубонной чумы у четырех индивидов [21, с. 131].

Следует также отметить и работу А.А. Хохлова и Е.П. Китова, которые провели обобщающее исследование дефектов травматического происхождения на палеоантропологических материалах эпохи раннего металла Волго-Уральского региона. Изучив краниологические материалы населения эпохи поздней бронзы, ученые установили тенденцию к снижению частоты встречаемости травматических повреждений от периода начала позднебронзового века - 12,9\%, покровское время - 4,2\%, к срубному времени $3,1 \%$. Причем авторы указали, что у срубников Волго-Уралья в основном распространены повреждения лицевого отдела черепа. У населения позднебронзового века, по мнению исследователей, доминируют травмы со следами заживления, полученные в результате ударов тупым навершием по черепу [22, c. 277-278].

Таким образом, можно указать, что палеопатологических исследований населения эпохи поздней бронзы с территории Восточной Европы и Сибири, проведено не много. В каждом случае материалы срубного времени уникальны и имеют свои особенности, что связано со спецификой ареала обитания, образом жизни и численностью выборки.

Данное исследование посвящено изучению особенностей распространения патологических отклонений на костных останках населения, происходящего из подкурганных захоронений срубного времени из могильника Красносамарский IV.

\section{Материал и методика исследования}

В процессе работы с антропологическим материалом применялась стандартная программа оценки встречаемости патологических состояний на костях посткраниального скелета и черепа, разработанная А.П. Бужиловой [23; 24]. Расчет палеодемографиче- 
ских характеристик проводился на основании построении таблиц смертности. Таблицы разбиты на 5летние когорты; возрастная шкала ограничена интервалом 50 и более лет; при отнесении индивидов в возрастные когорты применен принцип простой скользящей средней, использована стационарная, популяционная модель, разработанная Д. Богатенковым [25]. При фиксации дискретно варьирующих признаков использовалась оригинальная программа исследования, разработанная автором данной работы на основе трудов зарубежных исследователей [26-30].

Материалом исследования послужили костные останки 103 индивидов из курганов могильника Красносамарский IV, датирующиеся эпохой поздней бронзы. Материалы были получены в результате раскопок, проведенных отрядом средневолжской археологической экспедиции в 2010 и 2018 годах [31]. Данные памятники располагаются на территории муниципального района Кинельский Самарской области (рис. 1). Предварительно антропологический материал был изучен группой самарских антропологов, где основное внимание уделялось морфологическим аспектам строения скелетов [32, с. 108-130].

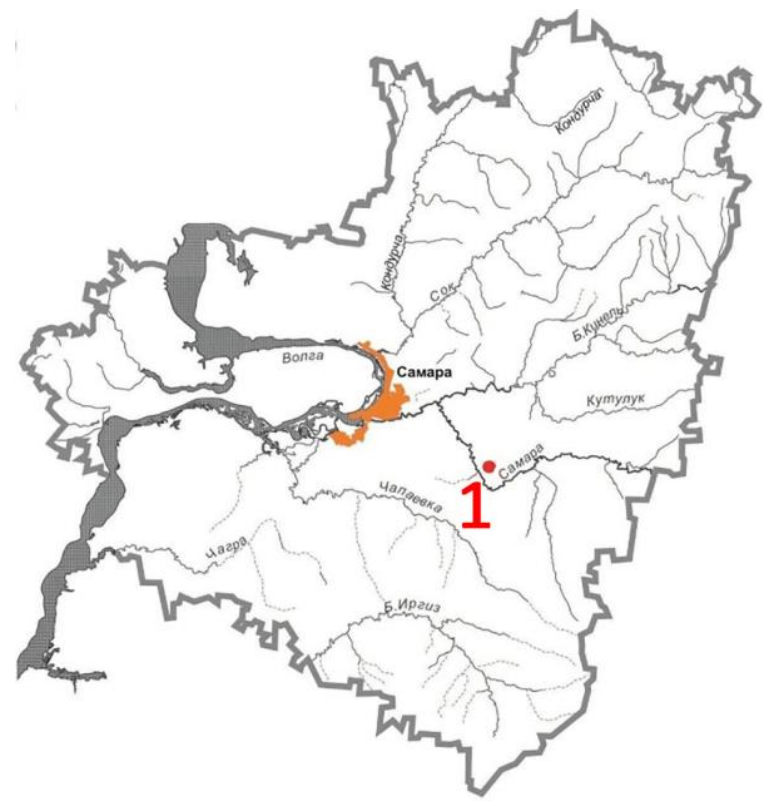

Рисунок 1 - Место расположения (1) могильника Красносамарский IV

Половозрастные особенности группь. Из 103 исследованных индивидов 21 скелет принадлежал мужчинам, в 16 случаях костные останки были женские. Скелеты 63 человек детские, костные останки трех индивидов подростковые. Также были изучены антропологические материалы одного молодого человека 15-19 лет, пол которого установить макроскопическими методами не удалось.
Соотношение по полу в изученной группе 131,3\% или 1,3 в пользу мужчин. Подавляющее большинство мужчин умирало в возрасте 15-19 и 30-34 лет, в то время как женщина в 30-34 года (табл. 1, 2).

Таблица 1 - Таблица смертности в группе срубного времени курганов Красносамарского

\begin{tabular}{|c|c|c|c|c|}
\hline \multirow{2}{*}{ Возраст } & $\begin{array}{c}\text { Суммарная } \\
\text { группа }\end{array}$ & $\begin{array}{c}\text { Муж- } \\
\text { чины }\end{array}$ & $\begin{array}{c}\text { Жен- } \\
\text { щины }\end{array}$ & $\begin{array}{c}\text { Только } \\
\text { взрослые }\end{array}$ \\
\hline $0-4$ & $D x$ & $D x$ & $D x$ & $D x$ \\
\hline $5-9$ & 26,0 & 0 & 0 & 0 \\
\hline $10-14$ & 3,0 & 0 & 0 & 0 \\
\hline $15-19$ & 8,0 & 5,0 & 2,0 & 8,0 \\
\hline $20-24$ & 1,0 & 0,0 & 1,0 & 1,0 \\
\hline $25-29$ & 5,0 & 4,0 & 1,0 & 5,0 \\
\hline $30-34$ & 11,0 & 5,0 & 6,0 & 11,0 \\
\hline $35-39$ & 4,0 & 4,0 & 0,0 & 4,0 \\
\hline $40-44$ & 5,0 & 2,0 & 3,0 & 5,0 \\
\hline $45-49$ & 2,0 & 1,0 & 1,0 & 2,0 \\
\hline$>50$ & 2,0 & 0,0 & 2,0 & 2,0 \\
\hline Сумма & 103 & 21 & 16 & 38 \\
\hline
\end{tabular}

Средний возраст смерти для суммарной серии взрослых людей находится на уровне 32,1 лет. Мужчины срубного времени, захороненные в курганах близ с. Красносамарское, жили практически на 5 лет меньше (30,2 года), чем женщины (35,0 лет) (табл. 2).

Дети чаще всего умирали в возрасте от 0 до 4 лет. Несколько реже встречаются захоронения детей возрастом 5-9 лет (табл. 1). Процент детской смертности в группе составляет $63,1 \%$, а количество умерших детей в возрасте от 0 до 1 года $-9,5 \%$.

Процент индивидов, доживших до старости или находящихся в возрасте старше 55 лет, составляет в исследуемой серии 5,3\% (табл. 2).

Прижсиненные и посмертные искусственные изменения на костных останках и зубах. Признаки искусственной деформации черепа были обнаружены на фрагментах черепной коробки подростка 14-15 лет из погребения 6 кургана 1 могильника Красносамарское IV. Характер искривления лобной, теменных и затылочной костей дает возможность предположить, что в данном случае использовались бандажи, позволяющие осуществить кольцевой тип деформации черепной капсулы.

Также следует обратить внимание на дефекты на зубах, которые можно отождествить с интерпроксимальными желобками, которые были обнаружены у 4 индивидов старше 35 лет, двух мужчин и двух женщин. Все они происходят из могильника Красносамарское IV (рис. 2). Дефекты чаще всего располагаются в межзубном пространстве на молярах нижней челюсти.

Таблица 2 - Основные палеодемографические характеристики в группе срубного времени могильника Красносамарское IV

\begin{tabular}{|l|c|c|c|c|}
\hline Основные палеодемографические характеристики & Всего & Мужчины & Женщины & Все взрослые \\
\hline Реальный объем выборки & 103 & 21,0 & 16,0 & 38,0 \\
\hline Средний возраст смерти в группе & - & 30,6 & 35,0 & 32,1 \\
\hline Средний возраст смерти без учета детей & 32,1 & 30,6 & 35,0 & 32,1 \\
\hline Процент детской смертности & - & - & - & - \\
\hline Процент детей в интервале 0-1 от NCD & - & - & - & - \\
\hline Процентное соотношение полов & 131,3 & - & - & 131,3 \\
\hline Процент индивидов данного пола & - & 56,8 & 43,2 & - \\
\hline Процент индивидов старше 50 лет & - & 0,0 & 12,5 & 5,3 \\
\hline
\end{tabular}




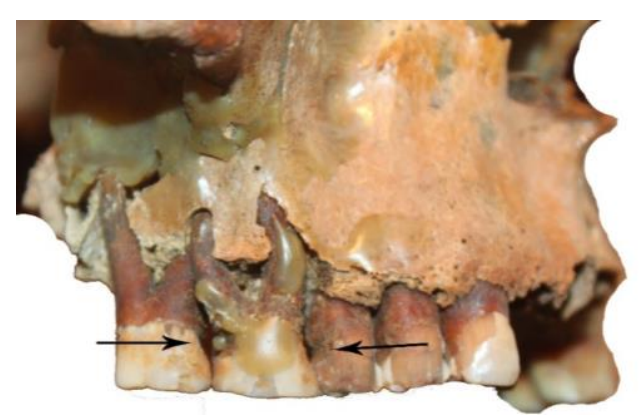

Рисунок 2 - Следы интерпроксимальных желобков на зубах верхней челюсти мужчины 40-45 лет из погребения 14 кургана 3 могильника Красносамарский IV

Патологии зубочелюстной системыл. В исследуемой серии зафиксировано 3 случая кариеса. Два наблюдения у мужчин и один раз кариес выявлен у женщины из погребения 26 кургана 4 могильника Красносамарский IV. Рассматривая патологии зубной системы у населения эпохи поздней бронзы на примере курганов близ с. Красносамарское, следует указать, что корреляции между случаями развития абсцессов, воспалительных процессов и кариесом, которые достаточно редко встречаются в исследуемой группе, отсутствуют.

Чаще всего в исследуемой группе наблюдается такое отклонений, как зубной камень - 97\% и признаки пародонтопатии - $63 \%$.

Обращает на себя внимание высокая частота фиксации дегенеративных изменений в области нижнечелюстного сустава, которые достигают 50\% (табл. 3) в серии, чаще наблюдаясь у мужчин. Также в мужской выборке достаточно часто наблюдаются сколы эмали на коронках зубов и эмалевая недостаточность. В случае с эмалевой гипоплазией в мужской выборке частота ее проявления достигает $65 \%$, а в суммарной группе $60 \%$.

В выборке неполовозрелых индивидов из патологий зубной системы распространены минерализованные отложения (64\%) и эмалевая гипоплазия (21\%) (табл. 3).

Таблица 3 - Частоты встречаемости зубочелюстных патологий у населения из подкурганных захоронений эпохи поздней бронзы могильника Красносамарский IV

\begin{tabular}{|l|c|c|c|c|}
\hline & $\begin{array}{c}\text { Взрос- } \\
\text { лые }\end{array}$ & $\begin{array}{c}\text { Мужчи- } \\
\text { ны }\end{array}$ & $\begin{array}{c}\text { Жен- } \\
\text { щины }\end{array}$ & Дети \\
\cline { 2 - 5 } & $N, \%$ & $N, \%$ & $N, \%$ & $N, \%$ \\
\hline S & 35 & 20 & 15 & 61 \\
\hline Абриес & $3(9 \%)$ & $2(10 \%)$ & $1(7 \%)$ & $0(0 \%)$ \\
\hline Зубной камень & $34(97 \%)$ & $0(0 \%)$ & $1(7 \%)$ & $0(0 \%)$ \\
\hline $\begin{array}{l}\text { Эмалевая } \\
\text { пипоплазия }\end{array}$ & $21(60 \%)$ & $13(65 \%)$ & $8(53 \%)$ & $13(21 \%)$ \\
\hline Потеря зуба & $6(17 \%)$ & $2(10 \%)$ & $4(27 \%)$ & $0(0 \%)$ \\
\hline Пародонтоз & $22(63 \%)$ & $10(50 \%)$ & $12(80 \%)$ & $0(0 \%)$ \\
\hline $\begin{array}{l}\text { Слом коронки, } \\
\text { сколы эмали }\end{array}$ & $11(31 \%)$ & $8(40 \%)$ & $3(20 \%)$ & $0(0 \%)$ \\
\hline $\begin{array}{l}\text { Патологическая } \\
\text { стертость зубов }\end{array}$ & $9(33 \%)$ & $5(25 \%)$ & $4(27 \%)$ & $0(0 \%)$ \\
\hline $\begin{array}{l}\text { Интерпроксима- } \\
\text { льные желобки }\end{array}$ & $4(11 \%)$ & $2(10 \%)$ & $2(13 \%)$ & $0(0 \%)$ \\
\hline $\begin{array}{l}\text { Дегенер. изм. } \\
\text { нижнечел. суст. }\end{array}$ & $12(50 \%)$ & $8(40 \%)$ & $4(27 \%)$ & $0(0 \%)$ \\
\hline
\end{tabular}

Самарский научный вестник. 2019. Т. 8, № 4 (29)
Признаки холодового стресса. Маркеры, указывающие на систематическое воздействие на организм человека низких температур, также присутствуют в группе, но достигают в серии умеренных значений $46 \%$. Признаки васкуляризации костной ткани по типу «апельсиновой корки» в области надбровья, в затылочной области и на скуловых костях фиксируются исключительно в серии взрослых индивидов. Причем очевидна половая направленность в распространении этого состояния костной ткани, которое в основном наблюдается у мужчин (табл. 4).

Таблица 4 - Частоты встречаемости некоторых индикаторов стресса у населения в курганах близ села Красносамарское эпохи поздней бронзы

\begin{tabular}{|c|c|c|c|c|}
\hline & $\begin{array}{c}\text { Взрос- } \\
\text { лые }\end{array}$ & $\begin{array}{l}\text { Муж- } \\
\text { чины }\end{array}$ & $\begin{array}{l}\text { Жен- } \\
\text { щины }\end{array}$ & Дети \\
\hline & $N, \%$ & $N, \%$ & $N, \%$ & $N, \%$ \\
\hline $\mathrm{s}$ & 35 & 20 & 15 & 61 \\
\hline $\begin{array}{l}\text { Васкулярная реакция } \\
\text { костной ткани (VIP) }\end{array}$ & $\begin{array}{c}16 \\
(46 \%)\end{array}$ & $\begin{array}{c}12 \\
(60 \%)\end{array}$ & $\begin{array}{c}4 \\
(27 \%)\end{array}$ & $\begin{array}{c}0 \\
(0 \%)\end{array}$ \\
\hline $\begin{array}{l}\text { Поротический } \\
\text { гиперостоз орбит } \\
\text { (Cribra orbitalia) }\end{array}$ & $\begin{array}{c}10 \\
(29 \%)\end{array}$ & $\begin{array}{c}7 \\
(35 \%)\end{array}$ & $\begin{array}{c}3 \\
(20 \%)\end{array}$ & $\begin{array}{c}26 \\
(43 \%)\end{array}$ \\
\hline $\begin{array}{l}\text { Поротический гиперос- } \\
\text { то3 костей свода черепа }\end{array}$ & $1(3 \%)$ & $0(0 \%)$ & $1(7 \%)$ & $1(2 \%)$ \\
\hline Пороз костей черепа & $\begin{array}{c}2 \\
(6 \%)\end{array}$ & $\begin{array}{c}1 \\
(5 \%)\end{array}$ & $\begin{array}{c}1 \\
(7 \%)\end{array}$ & $\begin{array}{c}38 \\
(62 \%)\end{array}$ \\
\hline Лобный гиперостоз (HFI) & $7(20 \%)$ & $4(20 \%)$ & $3(20 \%)$ & $0(0 \%)$ \\
\hline $\begin{array}{l}\text { Пальцевидные вдавле- } \\
\text { ния на костях черепа } \\
\text { со стороны эндокрана }\end{array}$ & $\begin{array}{c}9 \\
(26 \%)\end{array}$ & $\begin{array}{c}6 \\
(30 \%)\end{array}$ & $\begin{array}{c}3 \\
(20 \%)\end{array}$ & $\begin{array}{c}25 \\
(41 \%)\end{array}$ \\
\hline $\begin{array}{l}\text { Воспалительные процес- } \\
\text { сы на черепной коробке }\end{array}$ & $1(3 \%)$ & $0(0 \%)$ & $1(7 \%)$ & $0(0 \%)$ \\
\hline
\end{tabular}

Маркеры нехватки микроэлементов в организме. В исследуемой выборке взрослых индивидов состояния, указывающие на нехватку микроэлементов в организме, в целом встречаются умеренно (табл. 4). Однако следы поротического гиперостоза глазниц, который является маркером развития железодефицитной анемии в исследуемой серии, чаще наблюдается в мужской выборке, что в целом не характерно для палеопопуляций. Случай поротичекого гиперостоза костей свода черепа был выявлен только один раз у молодой женщины из погребения 20 кургана 2 могильника Красносамарский IV.

Практически полностью отсутствуют случаи встречаемости признаков воспалительных процессов на черепе и на костях посткраниального скелета у взрослых индивидов (табл. 5).

Таблица 5 - Показатели встречаемости признаков инфекций на костях посткраниального скелета у населения из курганов близ села Красносамарское эпохи поздней бронзы

\begin{tabular}{|l|c|c|c|c|}
\hline & $\begin{array}{c}\text { Взрос- } \\
\text { лые }\end{array}$ & $\begin{array}{c}\text { Муж- } \\
\text { чины }\end{array}$ & $\begin{array}{c}\text { Жен- } \\
\text { щины }\end{array}$ & Дети \\
\hline s & $N, \%$ & $N, \%$ & $N, \%$ & $N, \%$ \\
\hline $\begin{array}{l}\text { Воспалительные } \\
\text { процессы на костях } \\
\text { посткраниального } \\
\text { скелета }\end{array}$ & $\begin{array}{c}1 \\
(3 \%)\end{array}$ & $\begin{array}{c}1 \\
(5 \%)\end{array}$ & $\begin{array}{c}0 \\
(0 \%)\end{array}$ & $\begin{array}{c}15 \\
(25 \%)\end{array}$ \\
\hline Периостит голени & $1(3 \%)$ & $1(5 \%)$ & $0(0 \%)$ & $2(3,3 \%)$ \\
\hline $\begin{array}{l}\text { Следы специфиче- } \\
\text { ских инфекций }\end{array}$ & $0(0 \%)$ & $0(0 \%)$ & $0(0 \%)$ & $0(0 \%)$ \\
\hline
\end{tabular}


В то же время признаки анемии в виде «cribra orbitalia» глазниц, изменения костной ткани, в виде пороза костей свода и лицевого отделов черепа, указывающие на развитие такого заболевания как цинга, а также маркеры воспалительных процессов, в виде периоститов черепа и воспаления надкостницы на длинных костях скелета характерны для выборки неполовозрелых индивидов (табл. 4). Самым часто встречаемым патологическим отклонением является разреженность костной ткани в различных областях лицевого отдела черепа и свода черепа. Подобного рода состояния, которые можно отождествить с порозом надкостницы, зафиксированы в исследуемой группе у $62 \%$ неполовозрелых индивидов.

Из всех выявленных патологических отклонений только признаки внутричерепной гипертензии в одинаковой степени характерны как для детей, так и для взрослых.

Присутствуют в серии и маркеры развития гормональных нарушений. У мужчин и женщин срубного времени из курганов могильника Красносамарский IV такое патологическое отклонение, как внутренний лобный гиперостоз, фиксируется с одинаковой частотой в процентном соотношении как у мужчин, так и у женщин (табл. 4; рис. 3 ).

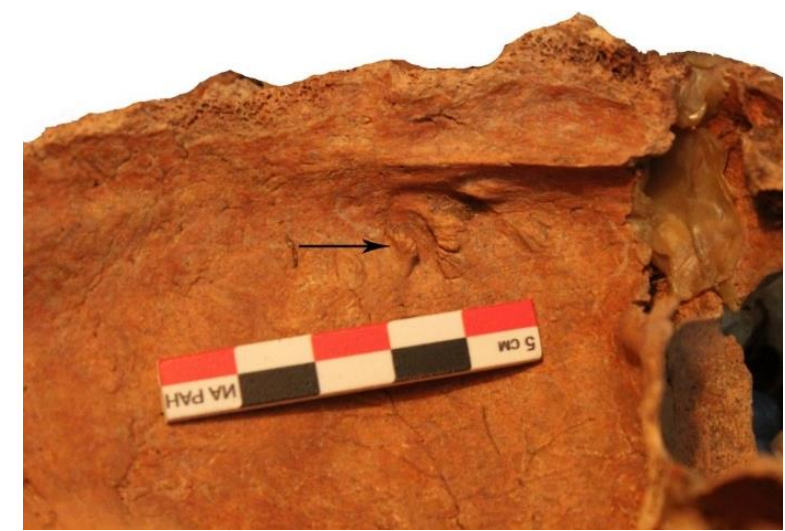

Рисунок 3 - Лобный внутренний гиперостоз на черепной коробке женщины 45-50 лет из погребения

15 кургана 1 могильника Красносамарский IV

Tравмы. Из 103 исследованных индивидов у 12 $(11,7 \%)$ были обнаружены травматические повреждения, из них один дефект обнаружен у ребенка, остальные случаи травм выявлены у взрослых индивидов $(35,1 \%)$. Всего зафиксировано 15 травм, у трех индивидов определено более чем одно повреждение.

Наблюдается четкая половая направленность в распределении травматических повреждений. У женщин выявлено только 3 перелома, у мужчин 11 повреждений костей скелета (табл. 6).

Таблица 6 - Частоты встречаемости травматических повреждений и заболеваний суставов у населения из курганов близ села Красносамарское эпохи поздней бронзы

\begin{tabular}{|l|c|c|c|c|c|c|c|c|c|}
\hline \multirow{2}{*}{$\begin{array}{l}\text { Локализация } \\
\text { повреждений }\end{array}$} & \multicolumn{3}{|c|}{ Взрослые } & \multicolumn{3}{c|}{ Мужчин } & \multicolumn{3}{|c|}{ Женщин } \\
\hline Свод черепа & 35 & 1 & 3 & 20 & 1 & 5 & 15 & 0 & 0 \\
\hline Лицевые травмы & 35 & 0 & 0 & 20 & 0 & 0 & 15 & 0 & 0 \\
\hline Артроз & 32 & 26 & 81 & 19 & 13 & 68 & 13 & 13 & 100 \\
\hline Артрит & 32 & 1 & 3 & 19 & 1 & 5 & 13 & 0 & 0 \\
\hline $\begin{array}{l}\text { Посткраниаль- } \\
\text { ный скелет } \\
\text { травмы }\end{array}$ & 32 & 11 & 34 & 19 & 8 & 42 & 13 & 3 & 23 \\
\hline $\begin{array}{l}\text { Посмертные } \\
\text { изменения }\end{array}$ & 32 & 1 & 3 & 19 & 1 & 5 & 13 & 0 & 0 \\
\hline
\end{tabular}

Определить четкие возрастные зависимости в распределении травм на антропологических материалах срубников из Красносамарских курганов затруднительно. Переломы позвоночника и длинных костей конечностей в одинаковой степени характерны как для молодых, так и для зрелых индивидов.

На черепных коробках обнаружено два дефекта компрессионный перелом костей свода черепа и травма лицевого отдела черепа с прижизненной утратой зубов верхней и нижней челюсти. Оба данных случая можно охарактеризовать как насильственные повреждения. Однако однозначно ответить на вопрос, боевые это ранения или они были получены в результате агрессивных действий, но не обязательно в ходе военных столкновений, ответить невозможно.

Из всех исследованных повреждений только ранение, обнаруженное у ребенка из погребения 11 кургана 3 могильника Красносамарский IV, имеет признаки смертельного характера и однозначно насильственного происхождения. Однако, как и в случае с ранениями на черепах, ответить на вопросы о причине и характере данного ранения не представляется возможным. Сопоставить данный случай с другими аналогичными случаями затруднительно по той причине, что они отсутствуют.

Все оставшиеся 11 травм являются переломами различных отделов посткраниального скелета. Чаще всего фиксируются переломы костей пояса и свободной верхней конечности с левой стороны (5 случаев), а также компрессионные переломы позвонков грудного (1 случай, рис. 4) и поясничного (4 наблюдения) отделов позвоночника.

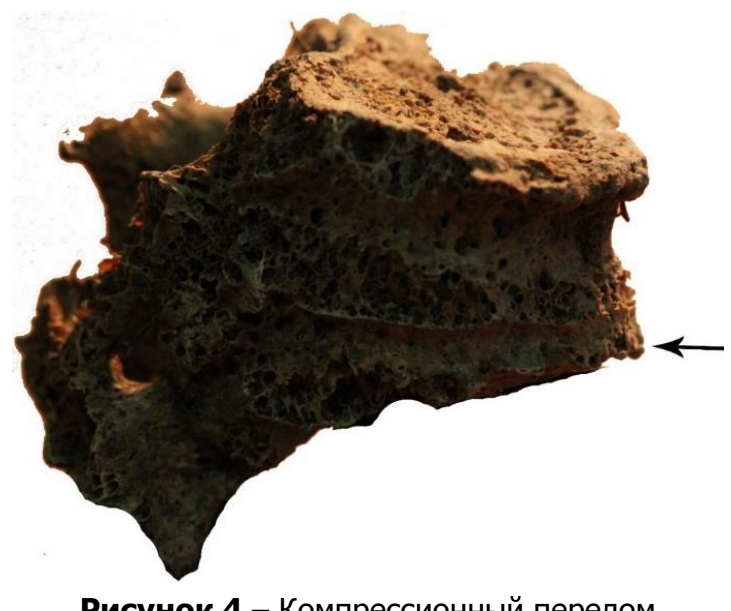

Рисунок 4 - Компрессионный перелом

грудного позвонка с последующим срастанием

с телом соседнего позвонка у мужчины 40-45 лет из погребения 15 кургана 1 могильника Красносамарский IV

Дистрофические изменения костно-суставного annapama. Изучение костей посткраниального скелета показало высокие частоты встречаемости патологий суставов и позвоночника (табл. $6,7,8)$.

Таблица 7 - Возрастные зависимости распространения заболеваний позвоночника и суставов у взрослого населения курганов близ села Красносамарское, \%

\begin{tabular}{|l|c|c|c|c|c|c|c|c|}
\hline \multicolumn{1}{|c|}{ Возраста } & \multicolumn{2}{|c|}{ Uvenis } & \multicolumn{2}{c|}{ Adultus } & \multicolumn{2}{c|}{ Matures } & \multicolumn{2}{c|}{ Senilis } \\
\hline Заболевания & С & $\Pi$ & С & $\Pi$ & C & П & С & $\Pi$ \\
\hline Мужчины & 0 & 0 & 64 & 91 & 86 & 100 & 0 & 0 \\
\hline Женщины & 0 & 0 & 88 & 100 & 100 & 100 & 100 & 100 \\
\hline $\begin{array}{l}\text { Взрослые, сум- } \\
\text { марная серия }\end{array}$ & 0 & 0 & 74 & 95 & 92 & 100 & 100 & 100 \\
\hline
\end{tabular}

Примечание. $C$ - заболевания суставов; $\Pi$ - заболевания позвоночника. 
Следует обратить внимание, что дегенеративные изменения на суставах скелета в исследуемой выборке чаще фиксируются на костных останках женщин. Это может объясняться двумя причинами. Первая причина - малочисленность женской выборки, а вторая - то, что в мужской серии индивидов молодого возраста значительно больше. Тем не менее наличие высоких значений заболеваний суставов в женской группе свидетельствует о том, что в изучаемой группе высокие физические нагрузки были характерны и для этой части населения.

Анализ возрастных зависимостей указывает на то, что изношенность костно-суставного аппарата у населения, захороненного в курганах могильника Красносамарский IV, наступала уже в молодом возрасте, и развитие деформирующего артроза и заболеваний позвоночника не имеет возрастной зависимости, а связано с профессиональной активностью индивидов, которая начиналась в возрасте старше 20 лет (табл. 7).

Как уже было указано, для исследуемой выборки характерна высокая частота поражения позвоночника дегенеративными изменениями 94\% (табл. 8). Чаще всего у мужчин и у женщин из курганов могильника Красносамарский IV встречается такое состояние позвонков, как остеофитоз. В подавляющем большинстве случаев он имеет вторую или первую степень развития, проявляясь в виде небольших разрастаний до 5 мм в длину, имеющих горизонтальную ориентировку. У мужчин остеофитозы чаще всего поражают поясничный отдел, а у женщин шейный отдел позвоночного столба.

Также часто в исследуемой выборке фиксируются так называемые узлы «Шморля», центральной или задней ориентации. У мужчин вдавления на телах позвонков в основном проявляются в грудном отделе, а у женщин в поясничном отделе позвоночника.

Признаки развития остеохондрозов встречаются реже по сравнению с другими патологиями позвоночного столба. Однако и в мужской и в женской серии они одинаково часто наблюдаются в шейном и поясничном отделах позвоночника.

Реже всего фиксировался спондилоартроз суставных отростков позвоночника, чаще всего он выявлялся в женской серии (табл. 8).

Ранняя диагностика заболеваний позвоночника и широкое их распространение у мужчин и у женщин свидетельствует о том, что физические нагрузки, вероятнее всего элеваторного характера, являлись определяющими в двигательной активности исследуемой серии.

Дискретные признаки на костях посткраниального скелета. Изучение костей посткраниального скелета взрослых индивидов позволило установить высокую частоту встречаемости некоторых фенов (табл. 9). Так, медиальная примыкающая фасетка на большой берцовой кости обнаружена у $36,4 \%$ человек (12 из 33 случаев), выемка на коленной чашечке от широкой мышцы бедра и ямка на коленной чашечке от широкой мышцы бедра зафиксированы у $27,3 \%$ индивидов (в обоих случаях по 9 наблюдений), фасетка Пуаррье, латеральная (боковая) примыкающая фасетка на большой берцовой кости, межмыщелковое отверстие на плечевой кости, anterior calcneal facet double - $24,1 \%$ ( 8 случаев), гипотрахантрическое отверстие, экзостоз в вертельной ямке, третий вертел $-18,2 \%$ (6 случаев) и венозный застой $-30,3 \%$ (10 наблюдений).
Высокая частота встречаемости дискретно-варьирующих признаков на костях посткраниального скелета, характерных как для мужской, так и для женской выборок, может косвенным образом указывать на то, что в курганах могильника Красносамарский IV было захоронено близкородственное население, a могильники являлись родовыми или клановыми кладбищами.

\section{Обсуждение}

Переходя к анализу полученных результатов, следует указать, что А.А. Хохловым уже были опубликованы демографические данные по антропологическим материалам, происходящим из могильника Красносамарский IV, но из раскопок более раннего времени. Полученные результаты сравнивались с синхронными сериями эпохи поздней бронзы бассейна реки Самара.

Изучив выборку из 25 индивидов, А.А. Хохлов указал на высокий процент детской смертности в исследуемой серии и на относительно высокую продолжительность жизни женщин. Автором было высказано предположение о высокой родовой активности женщин, что, вероятно, указывает на оседлость населения, хоронившего своих родственников в могильнике Красносамарский IV. Кроме этого, высокую детскую смертность А.А. Хохлов связал с усилением стрессового фона [8, с. 121].

Выводы, сделанные А.А. Хохловым, находят подтверждение и при анализе новых материалов из могильника Красносамарский IV, которые были раскопаны в 2018 году. В выборке также наблюдается повышенная смертность детей, в особенности в возрасте от 0 до 4 лет. Несколько реже встречаются погребения детей 5-9 лет. Причем у детей всех возрастов распространен ряд маркеров физиологического стресса в виде поротического гиперостоза орбит и развития пороза костей лицевого и мозгового отдела черепа. Продолжительность жизни женщин из погребений 2018 года могильника Красносамарский IV. имеют схожие параметры. В то же время средний возраст смерти мужчин в исследуемой нами серии имеет явные тенденции к понижению. По данному критерию изучаемая выборка с территории Самарской области находит аналогии с серией эпохи поздней бронзы района между Доном и рекой Быстрой до Цимлянского водохранилища, опубликованной Е.Ф. Батиевой [5]. Каких-либо объяснений понижения средней продолжительности жизни у населения позднебронзового века с этой территории исследователем не дано, указывается лишь, что для групп Подонья и Приазовья в это время характерны не самые высокие показатели по данному критерию [5, с. 243].

Специфической чертой исследуемой группы из могильников близ с. Красносамарское является фиксация на зубах у ряда индивидов интерпроксимальных желобков. Такая непреднамеренная деформация зубов считается самой распространенной среди древних популяций различных эпох с различной территории [33]. Наиболее ранние случаи интерпроксимальных желобков выявлены на материалах Ното erectus из Beijing, China, неандертальцев из La Quina [34]. На материалах эпохи бронзы Нижнего Поволжья они описаны у населения раннебронзового века, а также в серии покровской культуры из могильника Перекопка II [35, с. $48 ; 14]$. 
Таблица 8 - Частоты встречаемости заболеваний позвоночника у населения эпохи поздней бронзы из могильника Красносамарское IV

\begin{tabular}{|c|c|c|c|c|c|c|c|c|c|c|}
\hline \multicolumn{3}{|c|}{ Остеофитоз } & \multicolumn{3}{|c|}{ Узлы «Шморля» } & \multicolumn{3}{|c|}{ Остеохондроз } & \multirow{2}{*}{$\begin{array}{l}\text { Деформирующий } \\
\text { спондилоартроз }\end{array}$} & \multirow{2}{*}{\begin{tabular}{|c|} 
Общее число \\
дистрофических изменений \\
позвоночника
\end{tabular}} \\
\hline ШО & ГО & ПО & ШО & ГО & ПО & ШО & ГО & ПО & & \\
\hline \multicolumn{11}{|c|}{ Суммарная серия взрослых индивидов } \\
\hline 18 & 19 & 23 & 0 & 22 & 21 & 6 & 2 & 9 & 5 & 30 \\
\hline $56 \%$ & $59 \%$ & $72 \%$ & $0 \%$ & $69 \%$ & $66 \%$ & $19 \%$ & $6 \%$ & $28 \%$ & $16 \%$ & $94 \%$ \\
\hline \multicolumn{11}{|c|}{ Мужчины } \\
\hline \multicolumn{3}{|c|}{ Остеофитоз } & \multicolumn{3}{|c|}{ Узлы «Шморля» } & \multicolumn{3}{|c|}{ Остеохондроз } & & \multirow{2}{*}{\begin{tabular}{|c} 
Общее число \\
дистрофических изменений \\
позвоночника
\end{tabular}} \\
\hline ШО & $\Gamma \mathrm{O}$ & ПО & ШО & ГО & ПО & ШО & ГО & ПО & $\begin{array}{l}\text { Деформирующий } \\
\text { спондилоартроз }\end{array}$ & \\
\hline 7 & 10 & 13 & 0 & 14 & 11 & 2 & 2 & 4 & 1 & 16 \\
\hline $39 \%$ & $56 \%$ & $72 \%$ & $0 \%$ & $78 \%$ & $61 \%$ & $11 \%$ & $11 \%$ & $22 \%$ & $6 \%$ & $89 \%$ \\
\hline \multicolumn{11}{|c|}{ Женщины } \\
\hline \multicolumn{3}{|c|}{ Остеофитоз } & \multicolumn{3}{|c|}{ Узлы «Шморля» } & \multicolumn{3}{|c|}{ Остеохондроз } & & \multirow{2}{*}{\begin{tabular}{|c|} 
Общее число \\
дистрофических изменений \\
позвоночника \\
\end{tabular}} \\
\hline ШО & ГО & ПО & ШО & ГО & ПО & ШО & ГО & ПО & $\begin{array}{l}\text { Деформирующий } \\
\text { спондилоартроз }\end{array}$ & \\
\hline 11 & 9 & 10 & 0 & 8 & 10 & 4 & 0 & 5 & 4 & 14 \\
\hline $79 \%$ & $64 \%$ & $71 \%$ & $0 \%$ & $57 \%$ & $71 \%$ & $29 \%$ & $0 \%$ & $36 \%$ & $29 \%$ & 100 \\
\hline
\end{tabular}

Примечание. ШО - шейный отдел позвоночника; $Г O$ - грудной отдел позвоночника; ПО - поясничный отдел позвоночника.

Таблица 9 - Частота встречаемости некоторых дискретно-варьирующих признаков на костях посткраниального скелета у населения срубной культуры из курганов могильника Красносамарский IV

\begin{tabular}{|c|c|c|c|}
\hline \multirow{3}{*}{$\begin{array}{c}\text { Дискретные признаки } \\
\text { на костях посткраниального скелета }\end{array}$} & №/\% & №/\% & №/\% \\
\hline & Всего наблюдений 33 & Мужчины 19 & Женщины 14 \\
\hline & Суммарная серия & Мужчины & Женщины \\
\hline Spondilolisis - несращение дуги позвонка & $3 / 9,1$ & $1 / 5,3$ & $2 / 14,3$ \\
\hline Sacralisation 5 поясничного позвонка & $2 / 6,1$ & $1 / 5,3$ & $1 / 7,1$ \\
\hline Люмбализация первого поясничного позвонка & $1 / 3$ & $0 / 0$ & $1 / 7,1$ \\
\hline Poirier's facet - фасетка Пуаррье & $8 / 24,2$ & $5 / 26,3$ & $3 / 21,4$ \\
\hline Plaque - Налет на шейке бедренной кости & $2 / 6,1$ & $2 / 10,5$ & $0 / 0$ \\
\hline $\begin{array}{l}\text { Hypotrochanteric fossa - } \\
\text { гипотрахантрическое отверстие }\end{array}$ & $6 / 18,2$ & $3 / 15,8$ & $3 / 21,4$ \\
\hline $\begin{array}{l}\text { Exostosis in trochanteric fossa - } \\
\text { экзостоз в вертельной ямке }\end{array}$ & $6 / 18,2$ & $3 / 15,8$ & $3 / 21,4$ \\
\hline Third trochanter - третий вертел & $6 / 18,2$ & $3 / 15,8$ & $3 / 21,4$ \\
\hline $\begin{array}{l}\text { Medial tibial squatting facet - медиальная } \\
\text { примыкающая фасетка на большой берцовой кости }\end{array}$ & $12 / 36,4$ & $5 / 26,3$ & $7 / 50$ \\
\hline $\begin{array}{l}\text { Lateral tibial squatting facet - латеральная (боковая) } \\
\text { примыкающая фасетка на большой берцовой кости }\end{array}$ & $8 / 24,2$ & $5 / 26,3$ & $3 / 21,4$ \\
\hline $\begin{array}{l}\text { Supracondyloid process - } \\
\text { отросток над медиальным мыщелком }\end{array}$ & $1 / 3$ & $0 / 0$ & $1 / 7,1$ \\
\hline $\begin{array}{l}\text { Septal aperture - } \\
\text { межмыщелковое отверстие на плечевой кости }\end{array}$ & $8 / 24,2$ & $4 / 21,1$ & $4 / 28,6$ \\
\hline Pre-auricular sulcus & $2 / 6,1$ & $0 / 0$ & $2 / 14,3$ \\
\hline $\begin{array}{l}\text { The vastus notch - выемка на коленной чашечке } \\
\text { от широкой мышцы бедра }\end{array}$ & $9 / 27,3$ & $5 / 26,3$ & $4 / 28,6$ \\
\hline $\begin{array}{l}\text { Vastus fossa - ямка на коленной чашечке } \\
\text { от широкой мышцы бедра }\end{array}$ & $9 / 27,3$ & $7 / 36,8$ & $2 / 14,3$ \\
\hline Anterior calcaneal facet double & $8 / 24,1$ & $3 / 15,8$ & $5 / 35,7$ \\
\hline Peroneal tubercle - малоберцовый бугорок & $1 / 3$ & $1 / 5,3$ & $0 / 0$ \\
\hline Венозный застой & $10 / 30,3$ & $6 / 31,6$ & $4 / 28,6$ \\
\hline
\end{tabular}

С.С. Тур, М.П. Рыкун описали деформации на зубах у 17 скелетов андроновской культуры Алтая, предположив, что люди в это время использовали тонкие цилиндрические предметы (деревянные палочки, небольшие рыбьи кости или жесткие стебли травы) для очистки межзубных пространств и боковых поверхностей зубов [20].

Вполне вероятно, что практика использования твердых зубочисток у населения эпохи поздней бронзы из могильников близ с. Красносамарское имела лечебное или профилактическое значение при пародонтозе и отложении камня.

В целом для населения из погребений срубного времени могильника Красносамарский IV можно выделить следующие характеристики, которые определяют палеопатологический профиль исследуемой группы. Низкая частота встречаемости кариеса зубов и периапекальных отверстий различной этиологии, 
прижизненной утраты зубов, низкая процент встречаемости воспалительных процессов на костях черепа и посткраниального скелета, а также травм лицевого и мозгового отдела черепа, посмертных изменений на костях скелета. Средних значений достигают следующие параметры: патологическая стертость зубов и остеоартроз височно-нижнечелюстного сустава, встречаемость васкулярной реакции по типу «апельсиновой корки» и поротического гиперостоза орбит. Высокие показатели характерны для следующих патологических состояний: пародонтоз и зубной камень, в последнем случае в том числе и в группе неполовозрелых индивидов, завышенный процент встречаемости такого редкого патологического состояния, как внутренний лобный гиперостоз, широкое распространение заболеваний позвоночника, деформирующего артроза суставов и ненасильственных травм костей посткраниального скелета. Для серии неполовозрелых индивидов характерно широкое распространение признаков нехватки микроэлементов в организме, таких как Fе и витамина B12 (cribra orbitalia), витамина $\mathrm{C}$ (пороз костей свода и лицевого отделов черепа).

Выявленные патологические характеристики в целом соотносятся с результатами палеоантропологического анализа серии костяков из могильника Красносамарский IV, осуществленного А.А. Хохловым. Исследователь указывал, что на костных останках населения срубного времени могильника Красносамарский IV фиксируются различные маркеры эпидемиологического характера, а также связанные с заболеваниями суставов и специфики диеты [8, с. 122].

Таким образом, в результате проведенного патологического анализа серии костных останков срубной культуры из курганов могильника Красносамарский IV, раскопанных в 2018 г., удалось установить следующее:

1. По ряду палеоантропологических и палеопатологических критериев население эпохи поздней бронзы, погребенное в курганах близ села Красносамарское, выделяется на фоне других синхронных групп с территории Средней Волги, Нижнего Поволжья и Подонья, что говорит об уникальности исследуемой серии.

2. Специфичность изучаемой выборки по данным палеодемографии заключается в высокой детской смертности, низкой продолжительности жизни мужской части и относительно высокой продолжительности жизни женской части населения.

3. У носителей срубной культуры, захороненных в курганах Красносамарского IV, выделяется специфический комплекс патологических отклонений на зубной системе, который характеризуется низкой частотой кариеса и хронических воспалительных процессов и высокой частотой встречаемости зубного камня, пародонтоза, деформирующего артроза нижнечелюстного сустава, указывая на то, что группа специализировалась в диете на мясном комплексе с твердой пищей.

4. В серии взрослых индивидов, за исключением такого маркера как эмалевая гипоплазия, указывающего на то, что индивиды удачно пережили хронические заболевания в детстве, маркеры физиологического стресса встречаются сравнительно редко, а признаки воспалительных заболеваний практически отсутствуют. В то же время патологии, указывающие на нехватку микроэлементов в организме и система- тическое стрессовое давление, проявляющиеся в виде хронических заболеваний, приводивших к развитию поротического гиперостоза и пороза костей свода и лицевого отдела черепа, широко распространены в детской серии. Данная ситуация может быть индикатором специфической социально-культурной адаптации изучаемой группы к воздействию негативных факторов, например голодоморов или паразитарных инвазий.

5. Несмотря на то, что ряд исследователей, изучавших особенности и причины распространения внутреннего лобного гиперостоза у населения эпохи бронзы и раннего железного века Северного Кавказа и Нижнего Поволжья, пришли к выводу, что данное состояние характерно для оседлого населения, практикующее скотоводство или земледелие [36, с. 16 17], фиксация данной патологии в одинаковых высоких пропорциях у мужчин и женщин на материалах эпохи поздней бронзы с территории Средней Волги заставляет вновь искать причины появления HFI у срубного населения Самарского Поволжья в области биологии старения, условий жизни и социальной организации гендерной повседневности.

6. Травматизм костей посткраниального скелета, компрессионные травмы позвонков грудного и поясничного отдела и их положительная корреляция с развитием дистрофических изменений позвоночника и суставов у срубников Красносамарских курганов, вероятнее всего, является следствием специфического образа жизни или профессиональной деятельности, которая была сопряжена с систематической физической перегрузкой организма и переносом тяжестей.

7. Общая частота травматизма в серии из курганов могильника Красносамарский IV, по сравнению с синхронными выборками эпохи бронзы Восточной Европы, имеют значения выше среднего. В то же время травматизм в исследуемой серии у срубников Средней Волги не боевой (насильственный), а скорее бытовой или профессиональный.

\section{Список литературы:}

1. Дебец Г.Ф. Материалы по палеоантропологии СССР. Нижнее Поволжье // Антропологический журнал. 1936. № 1. С. 65-80.

2. Гинзбург В.В. Этнические связи древнего населения // Материалы и исследования по археологии СССР. 1959. № 60. С. 524-594.

3. Фирштейн Б.В. Антропологическая характеристика населения Нижнего Поволжья в эпоху бронзы (По материалам из раскопок в Волгоградской и Саратовской областях и в Калмыцкой АССР) // Памятники эпохи бронзы юга европейской части СССР. Киев: Наукова думка, 1967. С. 100-142.

4. Шевченко А.В. Антропология населения южнорусских степей в эпоху бронзы // Антропология древнего и современного населения европейской части СССР. Л.: Наука, 1986. С. 121-215.

5. Батиева Е.Ф. Палеодемография Подонья и Приазовья (эпоха бронзы) // Вестник антропологии. 2007. № 15. C. 236-245.

6. Балабанова М.А. К антропологии населения энеолита - ранней бронзы (по материалам могильников Волгоградской области) // Нижневолжский археологический вестник. 2016. Т. 15, № 1. С. 72-94.

7. Казарницкий А.А. Население Азово-Каспийских степей в эпоху бронзы (антропологический очерк). СПб.: Наука, 2012. 264 с. 
8. Хохлов А.А. Демографические особенности населения эпохи бронзы бассейна реки Самара // Материальная культура населения бассейна реки Самары в бронзовом веке. Самара: СамГПУ, 2003. С. 112-146.

9. Хохлов А.А. Морфогенетические процессы в Волго-Уралье в эпоху раннего голоцена (по краниологическим материалам мезолита - бронзового века): монография. Самара: СГСПУ, 2017. 368 с.

10. Рохлин Д.Г. Болезни древних людей (кости людей различных эпох нормальные и патологические изменения). М.; Л.: Наука, 1960. 302 с.

11. Дэрумс В.Я. Болезни и врачевание в древней Прибалтике. М.: Наука, 1970. 200 с.

12. Круц С.И. Палеоантропологические исследования степного Приднепровья (эпоха бронзы). Киев: Наукова думка, 1984. 206 с.

13. Бужилова А.П. Население Каргалов: палеоантропологические исследования // Каргалы. T. IV: Некрополи на Каргалах; население Каргалов палеоантропологические исследования. М.: Изд-во «Языки славянской культуры», 2005. 240 с.

14. Бужилова А.П. О населении эпохи бронзы по материалам раскопок в Ингушетии, 1996 г. // Opus: Междисциплинарные исследования в археологии: сб. ст. М.: ИА РАН, 2005. Вып. 4. С. 146-160.

15. Бужилова А.П. Ното sapiens: История болезни. М.: Языки славянской культуры, 2005. 320 с.

16. Батиева Е.Ф. Антропологические материалы из срубных погребений междуречья Дона и Чира // Курганные могильники раннесрубной культуры на Верхнем Чиру / Э.С. Шарафутдинова, В.Г. Житников. СПб.: СПбГУ, 2011. С. 162-176.

17. Аристова Е.С., Елясин П.А., Машак А.Н., Залавина С.В. Особенности пищевых специализаций населения барабинских степей эпохи неолит-бронза // Медицина в образовании. 2014. № 6. С. 19.

18. Шарапова С.В., Лоайе Ж., Солдаткин Н.В., Столярчик Э. Погребения бронзового века Южного Зауралья (палеопатологический аспект) // Исторические, философские, политические и юридические науки, культурология и искусствоведение. Вопросы теории и практики. 2016. № 1 (63). С. 199-203.

19. Куфтерин В.В., Нечвалода А.И. Антропологическое исследование скелетов из срубно-алакульского кургана Селивановского II могильника (Южное Зауралье) // Вестник археологии, антропологии и этнографии. 2016. № 4 (35). С. 79-89.

20. Тур С.С., Рыкун М.П. Население андроновской культуры Алтая по данным биоархеологического исследования // Известия Алтайского государственного университета. 2008. № 4-2 (60). С. 191-198.

21. Капинус Ю.О. Результаты антропологического исследования материалов срубной культуры курганного могильника Михайловский II // Урало-Поволжская археологическая конференция студентов и молодых ученых: мат-лы всерос. (с междунар. уч.) конф. Самара: Изд-во Самарского университета, 2018. C. 127-131.

22. Хохлов А.А., Китов Е.П. Дефекты травматического происхождения на палеоантропологических материалах эпохи раннего металла Волго-Уралья // Stratum plus. 2019. № 2. C. 267-280.

23. Бужилова А.П. Древнее население (палеопатологические исследования). М.: ИА РАН, 1995. 189 с.

24. Бужилова А.П. Палеопатология в биореологических реконструкциях // Историческая экология человека. Методика биологических исследований. М.: Старый Сад, 1998. С. 87-147.
25. Богатенков Д.В., Бужилова А.П., Добровольская М.В., Медникова М.Б. Реконструкции демографических процессов в прикаспийском Дагестане эпохи бронзы (по материалам раскопок археологического комплекса Великент в 1995-1998 гг.) // OPUS: Междисциплинарные исследования в археологии. 2008. № 6. C. 196-213.

26. Перерва Е.В. Дискретно-варьирующие признаки на костях посткраниального скелета: на примере антропологических материалов из некрополя Водянского городища // Вестник Волгоградского государственного университета. Серия 4: История. Регионоведение. Международные отношения. 2014. № 4 (28). C. $51-70$.

27. Fulginiti L.C. Discontinuous Morphological Variation at Grasshopper Pueblo, Arizona: The University of Arizona Publ., 1993. 222 p.

28. Finnegan M. Non-Metric Variation of the Infracranial Skeleton // J. Anat. 1978. Vol. 125, is. 1. P. 23-37.

29. Finnegan M., Faust M.A. Variants of the Femur // Research of Report 14: Bibliography of Human and NonHuman, Non-Metric Variation. 1974. № 3. P. 7-20. 41.

30. Saunders S.R. The Development and Distribution of Discontinuous Morphological Variation of the Human Infracranial Skeleton // Archaeological Survey of Canada. Ottawa: National Museums of Canada, 1978. P. 81.

31. Шалапинин А.А. Отчет о проведении охранно-спасательных археологических раскопок курганов №№ 1,3,4 курганного могильника Красносамарский IV на территории муниципального района Кинельский Самарской области в 2018 г. По Открытому листу № 2093. Самара, 2019. 243 с.

32. Хохлов А.А. Антропологические материалы курганного могильника Красносамарский IV (раскопки 2018 года) // Шалапинин А.А. Отчет о проведении охранно-спасательных археологических раскопок курганов №№ 1, 3, 4 курганного могильника Красносамарский IV на территории муниципального района Кинельский Самарской области в 2018 г. По Открытому листу № 2093. Самара, 2019. С. 108-130.

33. Brothwell D.R. Digging up bones. By. Ithaca, New York: Cornell University Press, 1981. 208 p.

34. Consiglio C. Non Masticastory Dental Lesion in the Study of Biology and Behavior of Ancient Populations: The contribution of the Stereomicroscopy and Scanning Electron Microscopy // Academic Dissertation. 2008. P. 443.

35. Дьяченко А.Н., Клепиков В.М., Кривошеев М.В., Балабанова М.А., Перерва Е.В., Яворская Л.В., Борисов А.В., Демкин В.А.,, Демкина Т.С., Удальцов С.Н., Хомутова Т.Э. Курганы бронзового века в излучине Дона (опыт комплексных археологических и естественнонаучных исследований). Волгоград: Волгоградский филиал ФГБОУ ВПО РАНХиГС, 2012. 159 c.

36. Бужилова А.П., Березина Н.Я., Перерва Е.В. Hyperostosis Frontalis Interna - признак пожилого возраста или индикатор образа жизни? // Известия Института антропологии МГУ: мат-лы всерос. науч. конф. с междунар. уч. «Современные проблемы биологии человека», посв. памяти заслуженного профессора МГУ Е.Н. Хрисанфовой / Е.Л. Воронцова (отв. ред.) и др. Вып. 3. М.: НИИ и Музей антропологии, 2018. С. 16-17.

Работа выполнена при поддержке гранта РНФ № 18-18-00137 «Контакты и взаимосвязи населения Урало-Поволжских и Казахстанских степей в период бронзы и раннего железа». 


\section{PALEOPATHOLOGICAL FEATURES OF THE LATE BRONZE AGE POPULATION: ANTHROPOLOGICAL SKELETAL MATERIALS EXCAVATED FROM BURIAL GROUNDS NEAR THE VILLAGE OF KRASNOSAMARSKOYE, SAMARA REGION}

(C) 2019

Pererva Evgeniy Vladimirovich, candidate of historical sciences, head of Scientific Department Volgograd Institute of Management - branch of the Russian Presidential Academy of National Economy and Public Administration (Volgograd, Russian Federation)

Kapinus Yulia Olegovna, researcher of Volga-Ural Paleoanthropological Research Center Samara State University of Social Sciences and Education (Samara, Russian Federation)

Abstract. The paper is devoted to the analysis of anthropological skeletal materials related to the Srubnaya culture and excavated in 2010 and 2018 in the mounds near the village of Krasnosamarskoye, Kinelsky District of the Samara Region. One hundred and three skeletal remains were studied. In the course of the examination, a standard program for fixing pathological conditions on human bones was applied. As a result of the work, it was possible to establish that the population of the Late Bronze Age buried in the mounds near the village of Krasnosamarskoe had a high infant mortality rate and a relatively short men's life expectancy. In the studied skeletal series, a specific pathological complex in the dental system is found. It indicates that the diet consisted mainly of meat and dairy. Widespread markers of micronutrient deficiencies in the body were observed on the children bones which is also an indicator of negative environmental and social factors such as famines or parasitic infestations. High frequency of discrete-varying characters on the bones of the postcranial skeleton indicates that a closely related population is buried in the mounds of the Krasnosamarsky IV burial ground. Specific traumatic injuries presence in buried skeletal remains as well as their positive correlation with diseases of the joints and spine allows us to assume its association with domestic or professional economic activity.

Keywords: paleoanthropology; paleopathology; diseases of ancient people; srubnaya culture; middle bronze age; burial grounds; Middle Volga; paleo demography; caries; tartar; hyperostosis frontalis interna; injuries; degenerative changes in joints and spine.

$* * *$

УДК 902.03

DOI 10.24411/2309-4370-2019-14206

Статья поступила в редакцию 08.09.2019

\section{ПЕРВЫЕ ПОПЫТКИ СОЗДАНИЯ АРХЕОЛОГИЧЕСКИХ КАРТ САМАРСКОЙ И СИМБИРСКОЙ ГУБЕРНИЙ НА РУБЕЖЕ XIX-XX ВЕКОВ}

(C) 2019

Сухова Олеся Константиновна, магистрант кафедры отечественной истории и археологии Самарский государственный социально-педагогический университет (г. Самара, Российская Федераџия)

Аннотация. В статье на общероссийском фоне рассматриваются первые попытки создания археологических карт Самарской и Симбирской губерний, организованные в Симбирске В.Н. Поливановым, в Самаре В.А. Миллером и Ф.Т. Яковлевым на рубеже XIX-XX вв. Впервые вводится в научный оборот археологическая карта В.А. Миллера и М.А. Миллера и, благодаря неопубликованным архивным материалам, выявляются источники информации, используемые для составления археологической карты Симбирской губернии. На примере метода анкетирования описываются первые шаги в деле централизованного сбора сведений о памятниках старины в российской провинции в XIX в. Отмечается большая роль вопросных листов Центрального статистического комитета 1873 г. и Московского археологического общества 1888 г. при решении задачи создания археологических карт отдельных губерний, а также анкет Симбирской губернской ученой архивной комиссии 1896 г. - для карты Симбирской губернии. Указывается на временной разрыв между учреждением в Самаре и Симбирске губернских ученых архивных комиссий - организаций, которые, как правило, ведали не только вопросами сохранения и обработки архивных документов, но и занимались археологическими изысканиями и проводили мероприятия по изучению древностей. Резюмируется, что Самарская и Симбирская губернии находились на разных уровнях вовлеченности в общероссийские процессы, но, так или иначе, в обеих губерниях были заложены предпосылки для составления планов дальнейшего археологического изучения двух регионов.

Ключевые слова: анкета 1873 г.; анкета 1888 г.; археология; археологическая карта; В.А. Миллер; М.А. Миллер; вопросные листы 1896 г.; В.Н. Поливанов; губернская ученая архивная комиссия; губернский статистический комитет; метод анкетирования; Московское археологическое общество; памятники археологии; Самарская губерния; самарский музей; Самарское археологическое общество; Симбирская губерния; Ф.Т. Яковлев.

В настоящее время в России проблема сохранения исторического и культурного наследия волнует ученых не меньше, чем в XIX в., когда российская археологическая наука только начинала институали-

зироваться. Археологические памятники разрушались не только из-за природных факторов, но и в ходе строительства, сельскохозяйственных работ, намеренных грабительских раскопок. Одним из глав- 